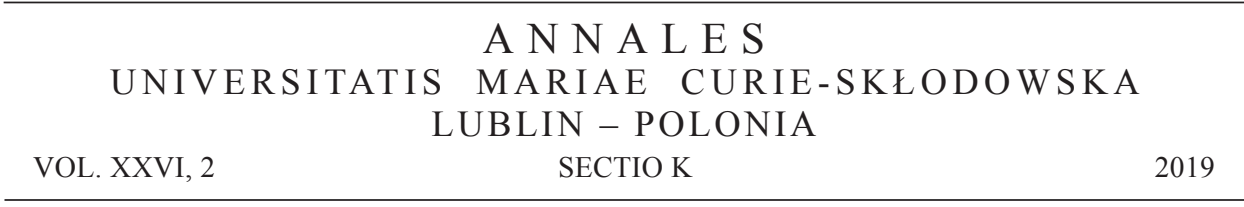

Charles University, Institute of Political Studies

\author{
DUŠAN BRABEC
}

ORCID ID: http://orcid.org/0000-0002-6604-9726

\title{
Participatory Budgeting in the Czech Republic between 2014 and 2018
}

\begin{abstract}
The first real participatory budget was implemented in the Czech Republic in 2014. Since that time, the number of participatory budgets implemented by Czech municipalities increased significantly. With the rising popularity of this mechanism, I have conducted a simple quantitative analysis of possibly all the cases of the participatory budgets that were implemented in the Czech Republic between 2014 and 2018. This analysis aimed to identify the main characteristics and features as well as general trends of participatory budgeting in the Czech environment. Most attention was focused on the indicators of attractiveness and effectiveness of participatory budgets in the Czech Republic such as the ratio of the funds allocated for participatory budgeting compared to municipalities' annual budgets or the connection between participatory budgets and voter turnout compared to other kinds of elections in the Czech Republic. This paper's main asset is that it identifies and summarises all the cases and the main characteristics of participatory budgeting that were held in the analysed time period in the Czech Republic.
\end{abstract}

Key words: participatory budgeting, the Czech Republic

\section{INTRODUCTION}

All around the world, participatory budgeting (hereinafter referred to as PB) is quite a known and used mechanism. It was estimated that only in Europe between 2005 and 2012, more than 13 hundred participatory budgeting instances took place, involving more than 8 million citizens [Sgueo 2016]. Despite this fact, the Czech experience with participatory budgeting did not start until $2014 .^{1}$

\footnotetext{
1 Although there were several initiatives that tried to implement the so-called participatory budgeting already in 2012 [rozpocetprovsechny.cz 2019].
} 
This study will focus on the development of the use of participatory budgeting since 2014 until 2018 in the Czech Republic. It aims to collect the data about all participatory budgets that took place in the analysed time period and to provide the reader with basic quantitative analysis of all the cases. The study will specifically focus on: 1) the number of participatory budgets, that were implemented by Czech municipalities each year in the analysed time period; 2 ) the amount of finances allocated by each municipality and also on the ratio of the allocated funds compared with annual budgets of municipalities; 3 ) the attractiveness of PBs in terms of voter turnout. The scope of this study is purely empirical so that I will omit the theoretical framing of the research dedicated to participatory budgeting. ${ }^{2}$

\section{PARTICIPATORY BUDGETING - DATA COLLECTION}

Even though participatory budgeting is getting more and more attention from the Czech municipalities each year - as the number of implemented participatory budgets is rising every year - the Czech Republic does not have any legal instrument that would deal with this tool. With the absence of duty of the municipalities to report implemented PBs they initiated, it is quite hard to identify all the cases that took place during the past few years.

To find all the cases, I had to rely on publicly available data such as the ones provided by NGOs; webpages of municipalities or newspapers. Because of this scarcity of sources, I had to contact the municipalities in those cases where some data were either missing, or other sources of these data were not uniform. It has to be said that because there is no legally binding reporting duty of municipalities to inform authorities about implemented PBs, in some cases, I struggled to get the data directly from the municipalities. Sometimes the city officials were not responding, and sometimes the municipalities (mostly those cases, where PBs were not successful and where only one edition of participatory budgeting took place) did not even collect the data about the participatory budgets that they had initiated. Despite these complications I was able to identify the vast majority of all the participatory budgets that were held between 2014 and 2018. But the question is: were all of these cases real PBs?

2 It should be at least mentioned that participatory democracy [Pateman 1970; 2012] and deliberative democracy [Cohen 1989; Bohman, Rehg 1997; Elster 1998] are two main theoretical frameworks that are being used for participatory budgeting. 


\section{BEGINNINGS OF PARTICIPATORY BUDGETING IN THE CZECH REPUBLIC - A PROBLEM WITH THE DEFINITION}

The first debates about the implementation of participatory budgeting in the Czech Republic were brought by citizens' initiatives such as "Alternativa Zdola". These initiatives aimed at informing Czech citizens and authorities about the assets of PB as mechanisms for local development and transparent distribution of municipalities finances. The initiatives drew mainly from foreign literature and experience of other cities and organisations that were involved in promoting participatory budgeting in other countries [Vojtíšková 2016a].

Particular participatory budgets (or procedures that were close to the key ideas of PBs) were introduced for the first time in the Czech Republic in 4 small municipalities (Nelahozeves, Pržno, Př́ibor and Třanovice) between 2012 and 2014 [rozpocetprovsechny.cz 2019]. In those municipalities, local authorities let the inhabitants decide, which pre-selected cases (mainly cultural or sports events or activates) they want to support financially. The residents could not propose any projects. They could only distribute finances allocated by the municipality for pre-selected cases. But, is the fact that the residents of these municipalities could participate and help the municipality with the allocation of its finances satisfying enough, so we can talk about participatory budgeting (it has to be said that these procedures called themselves "participatory budgeting")?

That brings us to a definition problem. Even in the Czech Republic the term "participatory budgeting" represented procedures that were quite different when speaking about their internal setting. Some of the initiated participatory budgeting procedures were very limited in terms of public participation (as specific cases mentioned above), some others offered much more deliberative approach. As Yves Sintomer, Carsten Herzberg and Anja Röcke [2008: 168] say: "It is therefore necessary to develop a methodological definition, which includes a set of minimal requisites in order to clearly differentiate this participatory procedure from others (such as neighbourhood funds) and which, at the same time, is comprehensive enough in order to give sufficient leeway to procedures with different specificities". They identify five key criteria: 1) the financial/budgetary dimension must be discussed as the participatory budgeting operates with limited financial resources; 2) the administration level of municipality (city district) has to be involved in the PB process; 3 ) also it has to be a repeated process (as one meeting or referendum is not sufficient); 4) the process must include some form of public deliberation; 5) finally, accountability on the output is required [Sintomer, Herzberg, Röcke 2008: 168]. According to these five criteria, the above-mentioned cases cannot be labelled "participatory budgets". 
The first real participatory budgeting (that met all of the five criteria specified by Sintomer et al. [2008: 168]) was held in the city district Prague 7 in 2014 - where the municipality allocated CZK 1 million. Unfortunately, this first PB had several problems (insufficient information campaign, only one meeting with citizens, very few places, where citizens could vote, etc.), which resulted in very low voter turnout (only $0.15 \%$ of the inhabitants of the city district) [Vojtíšková 2016b]. Nevertheless, since that time, the number of municipalities that are implementing PB procedures is increasing every year.

In total, I was able to identify 44 municipalities that were using PB (either successfully or unsuccessfully) since 2014. Those procedures more or less met the conditions of PBs. Between 2014 and 2018 (I mapped only those procedures that already ended as some others are still being carried out), 98 participatory budgeting periods took place in the Czech Republic. Every year, the number of municipalities that were implementing PB was increasing - I have prepared a quantitative analysis of the cases that were, with no doubt, PBs in its nature and design (because there were also some procedures that called themselves $\mathrm{PB}$, but their configuration was of different nature). Also, some of the municipalities that carried out these procedures did not provide any data, which made the analysis of these cases impossible.

I was able to collect data about 81 participatory budgets that were carried out in the years 2014-2018 in 40 different municipalities. In 2014, we had only one municipality using PB (unsuccessful case of city district Prague 7), in 2015 - there were 3 PB procedures. In 2016 - 13, in 2017 - 31, and in 2018 - 33 PB procedures in the Czech Republic. It has to be said that most of the times these procedures did not start and finish in the one-year period - so for the purposes of the quantitative analysis, I have assigned each procedure to the year when it was launched (Figure 1).

It is evident that most of the times, the municipalities that implemented PB used this mechanism in the following year as well. It is expected that the number of participatory budgets implemented in the Czech Republic will increase in 2019 at least to 53 cases [participativnirozpocet.cz 2018]. Very important characteristic of each of the individual participatory budgets is the amount of allocated finances by the municipality. Funds allocated for PB procedures differ quite significantly. From CZK 100,000 (EUR 3,860) allocated by the small city of Hejnice (approximately 2,700 inhabitants) to CZK 30,000,000 (EUR 1.16 million) provided by the second Czech biggest city - Brno (380,000 inhabitants). As the amount of allocated finances varies a lot, it is much more useful to look at the ratio of allocated money compared with an overall budget of the municipalities (or its expenditure component to be more precise). Municipalities allocated on average $0.55 \%$ of their annual budget for the PB - the biggest share of its budget was allocated by the small city of Dobřejovice in $2016-2.58 \%$. Only $12 \%$ of all municipalities (10 of 81 ) 


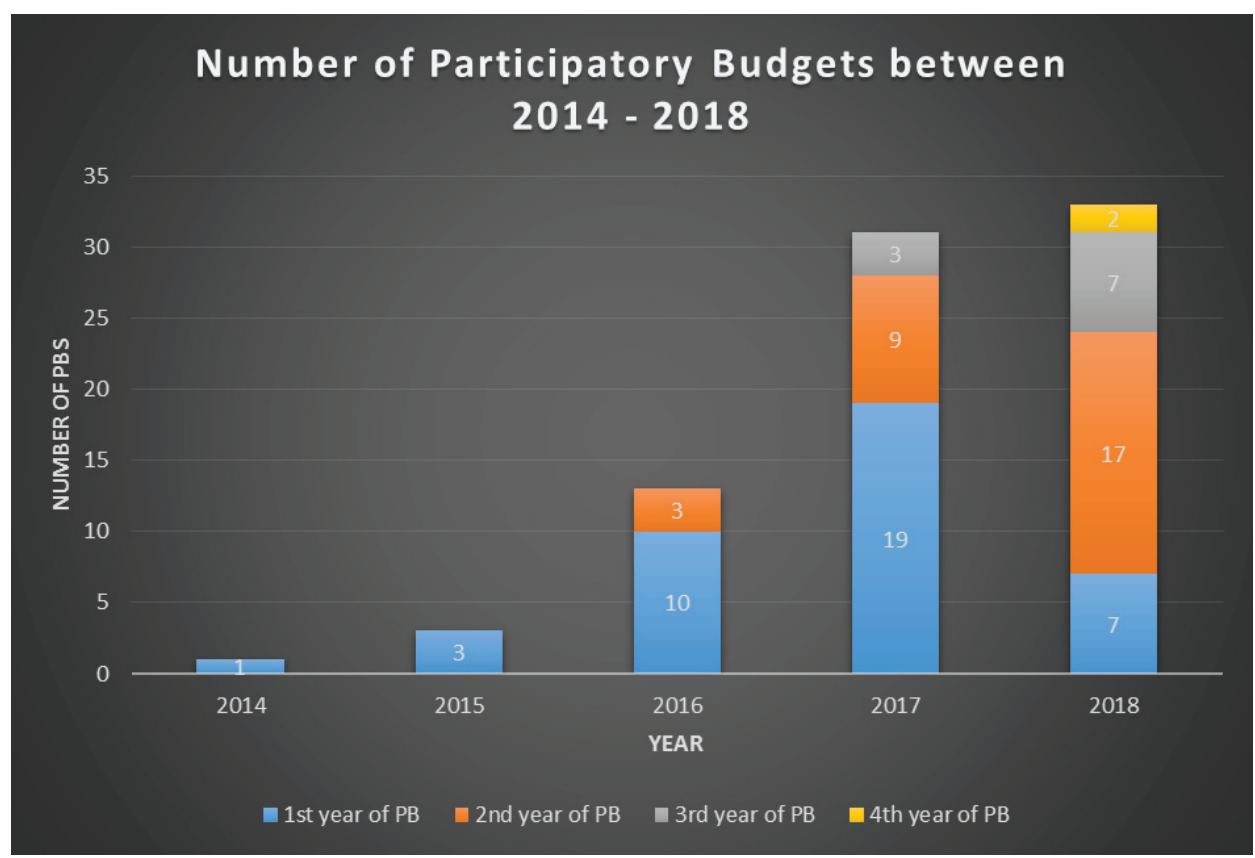

Figure 1. Number of participatory budgets between 2014 and 2018

The figure shows how many PBs were implemented each year. Each colour represents a number of municipalities that implemented the PB: a) for the first time (blue); b) for the second time (orange), c) for the third time (grey); d) for the fourth time (yellow).

Source: Author's own study.

allocated more than $1 \%$ of its annual budgets for PB procedures. The municipalities were at least increasing the budget of their PB procedures if previous PB periods held by the municipalities were successful - as $48 \%$ of those municipalities, which held more than one PB procedure, at least once increased the PB budget for upcoming seasons - on average, they increased the budget by $30 \%$ (the other $52 \%$ of municipalities allocated the same amount of money as in the previous year) (Figure 2).

Let us consider the amount of money allocated by the municipalities on $\mathrm{PB}$ procedure per resident of the city (who was at the of age of 15 or above - as most of the times, citizens who were older than 15 years were allowed to participate in PB procedure - either propose projects or vote on them). On average, the citizens could decide directly, how to spend approximately CZK 100 (EUR 4). When talking about this statistic, the most generous city was Ŕíčany (small city near Prague), which enabled each citizen above 15 to spend more than CZK 400.

In reality, however, the citizens were deciding on much higher amounts of money - why is that? Because the voter turnout, when voting on the proposed projects, was quite low. On average, the voter turnout was $6 \%$ (the biggest voter turnout was in 


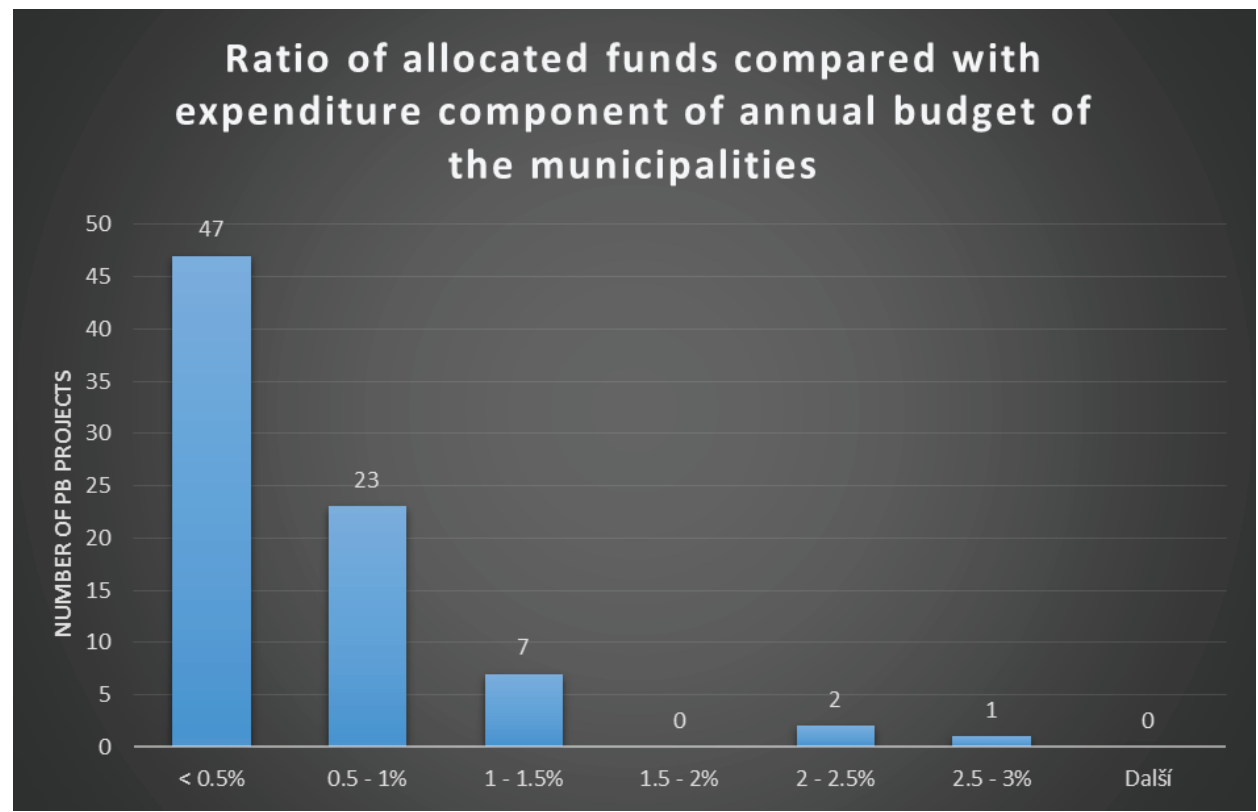

Figure 2. Ratio of allocated funds compared with expenditure component of the annual budget of analysed municipalities

The X-axis (bins) represents the percentage of the expenditure component of annual budget that was allocated for PB procedures. Y-axis shows number of municipalities that falls into each of the bins.

Source: Author's own study.

2017 in Mníšek pod Brdy - 38\%). The citizens who voted for some of the proposed PB projects were deciding on more than CZK 2,900 (approx. EUR 110). In the city district Prague 20, each voter directly decided on almost CZK 18,000 (approx. EUR 695) from the participatory budget worth CZK 1 million (more than EUR 30,000 EUR) - because only 56 (out of 12,795 eligible voters) citizens voted on proposed projects (Figure 3).

In Figure 3 there is depicted voter turnout in each of the municipalities that carried out a PB procedure in 2018. It is obvious that participatory budgeting is not as attractive as different kinds of elections, where the citizens can show their preferences. It is not surprising that the elections with the highest turnout are presidential elections. Parliamentary elections are perceived by citizens as second most important, which corresponds with the rates of voter turnout. Local elections (at least in the analysed municipalities) are on the third place when talking about voter turnout. Unfortunately, participatory budgeting is not close to the turnout of the traditional elections in terms of voter turnout.

As can be seen, the trend of the voter turnout for different municipalities is not the same. As depicted in Table 1, in some municipalities, the voter turnout increased 
in consequential rounds of participatory budgeting. In other cities, citizens showed less interest in the following rounds.

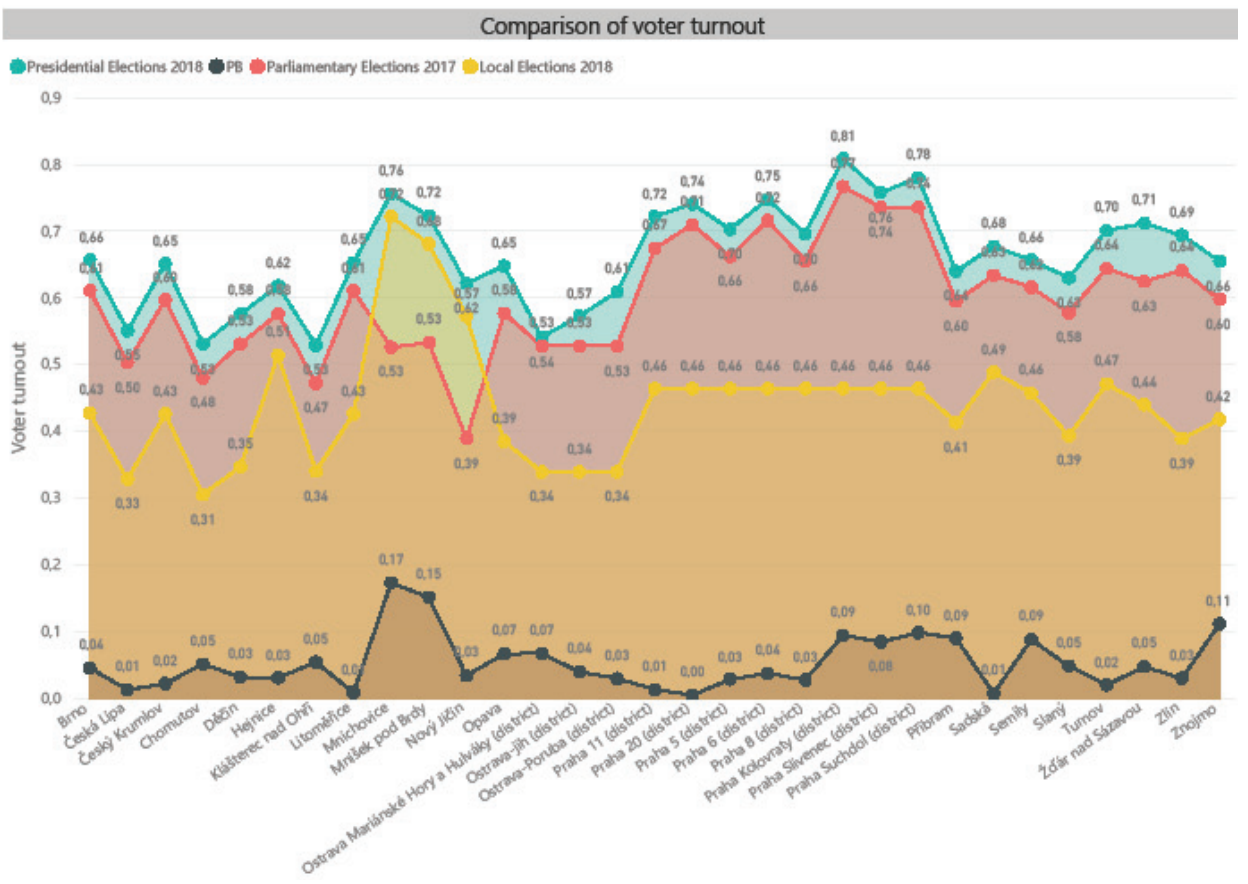

Figure 3. Voter turnout comparison

The figure illustrates the turnout of different kinds of election in the municipalities that used participatory budgeting in 2018 . Green dots represent voter turnout during second round of presidential election that took place in January 2018. Red dots represent voter turnout of parliamentary elections that took place in October 2017. Yellow dots illustrate turnout of local elections from October 2018. Black dots show turnout for voting phase of parliamentary budgeting procedures that took place in 2018 . $^{3}$

Source: Author's own study.

This study is of descriptive nature and uses mainly data that were publicly available. It would be necessary to conduct a qualitative analysis, which would aim to identify the biggest challenges that the municipalities are facing when implementing participatory budgeting. It would be crucial to investigate, how much (or to what extent) are the municipalities fulfilling the necessary criteria of participatory budgeting proposed by Sintomer et al. [2008: 168]. All of the analysed Czech cases of participatory budgeting meet these above-mentioned criteria, but some of the municipalities meet them to a larger extent than others. It would be interesting to

3 During the voting phase of PBs even citizens who were older than 15 years were allowed to vote. In other elections (as depicted in Figure 3), only citizens older than 18 could vote. 
Table 1. Trends of voter turnout in different municipalities

\begin{tabular}{|c|c|c|c|c|}
\hline Municipality & $\begin{array}{l}1^{\text {st }} \text { round } \\
\text { of } \mathrm{PB}\end{array}$ & $\begin{array}{l}2^{\text {nd }} \text { round } \\
\text { of } \mathrm{PB}\end{array}$ & $\begin{array}{l}3^{\text {rd }} \text { round } \\
\text { of } \mathrm{PB}\end{array}$ & $\begin{array}{l}4^{\text {th }} \text { round } \\
\text { of } \mathrm{PB}\end{array}$ \\
\hline Brno & $3.62 \%$ & $4.50 \%$ & - & - \\
\hline Český Krumlov & $1.96 \%$ & $2.15 \%$ & - & - \\
\hline Hejnice & $1.07 \%$ & $3.01 \%$ & - & - \\
\hline Chomutov & $5.07 \%$ & $5.06 \%$ & - & - \\
\hline Chýně & $12.90 \%$ & $11.42 \%$ & - & - \\
\hline Klášterec nad Ohří & $6.85 \%$ & $5.37 \%$ & - & - \\
\hline Litoměřice & $0.81 \%$ & $0.99 \%$ & $0.81 \%$ & - \\
\hline Mnichovice & $14.38 \%$ & $14.67 \%$ & $17.26 \%$ & - \\
\hline Mníšek pod Brdy & $38.05 \%$ & $15.10 \%$ & - & - \\
\hline Opava & $5.69 \%$ & $6.62 \%$ & - & - \\
\hline Ostrava Mariánské Hory a Hulváky (district) & $4.12 \%$ & $8.46 \%$ & $6.70 \%$ & - \\
\hline Ostrava-jih (district) & $4.20 \%$ & $4.30 \%$ & $3.89 \%$ & - \\
\hline Ostrava-Poruba (district) & $2.38 \%$ & $1.84 \%$ & $2.93 \%$ & - \\
\hline Praha 10 (district) & $5.33 \%$ & $4.87 \%$ & $2.33 \%$ & $2.73 \%$ \\
\hline Praha 20 (district) & $0.59 \%$ & $0.44 \%$ & - & - \\
\hline Praha 3 (district) & $3.60 \%$ & $1.83 \%$ & - & - \\
\hline Praha 5 (district) & $0.79 \%$ & $2.77 \%$ & - & - \\
\hline Praha 6 (district) & $3.37 \%$ & $3.71 \%$ & - & - \\
\hline Praha 8 (district) & $4.22 \%$ & $2.70 \%$ & - & - \\
\hline Praha Kolovraty (district) & $13.58 \%$ & $9.40 \%$ & - & - \\
\hline Praha Slivenec (district) & $5.43 \%$ & $8.40 \%$ & - & - \\
\hline Praha Suchdol (district) & $7.72 \%$ & $9.80 \%$ & - & - \\
\hline Praha Zbraslav (district) & $8.38 \%$ & $18.90 \%$ & $9.36 \%$ & - \\
\hline Říčany & $8.45 \%$ & $5.98 \%$ & $5.55 \%$ & - \\
\hline Sadská & $3.22 \%$ & $0.66 \%$ & - & - \\
\hline Semily & $1.74 \%$ & $2.44 \%$ & $4.09 \%$ & $8.76 \%$ \\
\hline Slaný & $7.84 \%$ & $4.77 \%$ & - & - \\
\hline Turnov & $25.60 \%$ & $1.94 \%$ & - & - \\
\hline Žd’ár nad Sázavou & $2.44 \%$ & $2.83 \%$ & $4.69 \%$ & - \\
\hline
\end{tabular}

The table shows how the voter turnout changed in the municipalities that took use of participatory budgeting more than once in the analysed time period. In total, 11 out of 40 analysed municipalities used participatory budgeting only once between 2014 and 2018. Highlighted in red are those editions where the voter turnout was lower than in the previous edition. PB editions where the voter turnout increased in comparison with the previous PB edition are highlighted in green.

Source: Author's own study. 
analyse all the PBs from a qualitative perspective to find out where the PBs are more effective and attractive and what are the main reasons for it.

\section{USE OF PARTICIPATORY BUDGETING IN DIFFERENT AREAS}

Ideas to implement participatory budgeting in the Czech Republic are not that old (even though the mechanism itself was firstly introduced in Porto Alegre in the 1980s). In the Czech Republic, the first public debates and seminars, where the participatory budgeting as a tool for local development was introduced, took place in 2011 [Vojtíšková 2016a]. Despite the fact that since that time, participatory budgeting became much more popular, we still do not have any legal framework that would deal with PBs in the Czech Republic. Participatory budgeting does not even belong to "big" political topics. It is brought up only during local elections, most of the time, by politicians, who are trying to run for office at the municipal level ${ }^{4}$ [parlamentnilisty.cz 2014].

Even though participatory budgeting does not belong to frequently discussed topics (at least among national politicians), it is interesting that this mechanism is used for different purposes. Since 2014, participatory budgeting has been used by Pirates Party for the distribution of a portion of funds they get from the state [Ferjenčík 2014]. Every member of Pirates Party can prepare and submit a project (it has to be project that is publicly beneficial) and consequentially, the members of the party then decide on the level of individual projects' funding. Pirates have been using PBs internally for last 5 years [Pirátská strana 2019]. Participatory budgeting is also becoming a mechanism that is being implemented by Czech grammar and high schools [Vojtíšková 2016c].

\section{CONCLUSIONS}

The aim of this paper was to identify and summarise all the cases, where Czech municipalities implemented participatory budgeting as a mechanism for transparent distribution of finances between 2014 and 2018. As the effort of the municipalities to incorporate their citizens to participate in public affairs increased over the past ten years, the number of different budgeting mechanisms and tools increased quite significantly. It was thus inevitable to find a clear definition or to identify criteria that would help in recognising cases, where the municipalities implemented participatory budgeting, and not other instruments. Based on five criteria postulated by Sintomer et al. [2008: 168], I was able to identify more than 80 cases of more or less successful

4 This is the case of Jan Tř́íska [2014] from ČSSD or Michal Pilař [2018] from TOP09. Participatory budgeting was also brought up by other politicians during the local election campaigns. For example, Vít Rakušan [2018], chairman of STAN or a local politician Jakub Stárek [2018] tried to emphasize the need to implement PBs at the local level. 
participatory budgets in the Czech Republic between 2014 and 2018. Unfortunately, not all of the municipalities that have implemented participatory budgeting in the analysed time period, provided the data about the progress of their PBs. As there is no legal framework that would deal with the participatory budgeting (either implementing this mechanism or at least binding the municipalities to collect and publish the data of past editions of PBs), my analysis was entirely depended on publicly available sources (webpages of municipalities; newspapers or data provided by NGOs) or, at least in some cases, on the data collected directly from the municipalities officials.

In the end, I was able to conduct an analysis of 81 editions of PBs that took place in 40 different municipalities between 2014 and 2018. The most positive fact that came out of the analysis is that each year, the number of PBs increased - in the last year of analysis (2018), I identified 33 municipalities that took advantage of participatory budgeting. For this year (2019) it is expected that even more municipalities (over 50) will implement PB. One of the goals of the analysis was to assess the attractiveness of the PBs that could be derived from the municipal spending on PBs or voter turnout during the voting phase of PBs. On average, the municipalities allocated to PBs only $0.55 \%$ of its expenditure component of municipal annual budget. Even the average voter turnout was quite low. With only $6 \%$ of the voter turnout on average, the participatory budgeting is far behind other kinds of elections that the citizens can participate in. Moreover, a common observable trend of the voter turnout for consequential PB editions was not present, as in some municipalities more citizens participated in following editions of PBs, but in other municipalities, they were not successful with attracting more citizens in consequential rounds.

This study was rather of descriptive nature, and its goals were to identify and analyse all the participatory budgeting cases that took place between 2014 and 2018 . It would be interesting to conduct qualitative research that would help to better understand the internal mechanisms of participatory budgeting implemented in the Czech Republic. The biggest asset of this paper is its summarising aspect that could potentially help other researchers with further studies on participatory budgeting in the Czech Republic. Based on the results of this study, it would be also interesting to prepare a comparative analysis of different cases (either Czech or international) that could serve as a foundation for future policy papers.

\section{BIBLIOGRAPHY}

Bohman, J., Rehg, W. 1997. Deliberative Democracy, MIT Press, Cambridge, MA.

Cohen, J. 1989. Procedure and Substance in Deliberative Democracy, [in:] The Good Polity: Normative Analysis of the State, A. Hamlin, P. Pettit (eds.), Blackwell, Oxford.

Elster, J. 1998. Deliberative Democracy, Cambridge University Press, Cambridge.

Ferjenčík, M. 2014. Piráti hledaji hranice demokracie, zaváději participativni rozpočet, http://denikreferendum.cz/clanek/17190-pirati-hledaji-hranice-demokracie-zavadeji-participativni-rozpocet (access: 19.10.2019). 
Pateman, C. 2012. Participatory Democracy Revisited, "Perspectives on Politics", vol. 10(1), pp. 7-19, DOI: https://doi.org/10.1017/S1537592711004877.

Pateman, C. 1970. Participation and Democratic Theory, Cambridge University Press, Cambridge.

Parlamentnilisty.cz, 2014. Participativni rozpočet pronikl mezi volebni témata, https://www.parlamentnilisty.cz/ zpravy/tiskovezpravy/Participativni-rozpocet-pronikl-mezi-volebni-temata-338293 (access: 19.10.2019).

Participativnirozpocet.cz, 2018. Participativní rozpočty v České republice v roce 2018, https://www. participativni-rozpocet.cz/blog/2019/03/11/participativni-rozpocty-v-ceske-republice-v-roce-2018/ (access: 19.10.2019).

Pilař, M. 2018. Prosadime participativní rozpočet, https://www.top09.cz/regiony/pardubicky-kraj/regionalni -organizace/ro-pardubice/mo-pardubice/pilar-prosadime-participativni-rozpocet-24885.html (access: 19.10.2019).

Pirátská strana, 2019. Participativní rozpočet, https://wiki.pirati.cz/fo/rozpocty/participativni/start (access: 19.10.2019).

Rakušan, V. 2018. Využívejme lokální referenda, https://www.starostove-nezavisli.cz/info-a-media/vystupy -z-medii/rakusan-vyuzivejme-lokalni-referenda (access: 19.10.2019).

Rozpocetprovsechny.cz, 2019. 1. obecní participativní rozpočty $v \breve{C} R$ v letech 2012-2014, https://rozpocetprovsechny.cz/ (access: 19.10.2019).

Sgueo, G. 2016. Participatory Budgeting: An Innovative Approach, https://ssrn.com/abstract=2712213 (access: 19.10.2019).

Sintomer, Y., Herzberg, C., Röcke, A. 2008. Participatory Budgeting in Europe: Potentials and Challenges, "International Journal of Urban and Regional Research", vol. 32, pp. 164-178, DOI: https://doi. org/10.1111/j.1468-2427.2008.00777.x.

Stárek, J. 2018. Projev v rámci politické diskuse 28. kongresu ODS, https://www.ods.cz/kongres/novinky/ clanek/14842-projev-v-ramci-politicke-diskuse-28-kongresu-ods (access: 19.10.2019).

Tř́ska, J. 2014. Proč by i Ústi nemohlo mít svi̊j participativní rozpočet?, https://www.parlamentnilisty.cz/politika/politici-volicum/Triska-CSSD-Proc-by-i-Usti-nemohlo-mit-svuj-participativni-rozpocet-336283 (access: 19.10.2019).

Vojtíšková, K. 2016a. Když o rozpočtu rozhodují obyčejní občané, http://www.socialwatch.cz/?p=899 (access: 19.10.2019).

Vojtíšková, K. 2016b. Česká cesta k participativnímu rozpočtování, "Smart Cities”, vol. 16(2).

Vojtišková, K. 2016c. Školy uči žáky demokracii pomocí participativního rozpočtování, "Smart Cities”, vol. 16(4).

\section{BIOGRAPHY}

Dušan Brabec, a PhD student at the Institute of Political Studies, Faculty of Social Sciences, Charles University. He specializes in social network analysis and its application in political science. He is interested in the issue of the adoption of instruments of direct democracy in the Czech Republic.E-mail: dusan.brabec@fsv.cuni.cz

\section{ACKNOWLEDGEMENTS}

This study was supported by the Charles University Research Programme "Progres" Q18 - Social Sciences: From Multidisciplinarity to Interdisciplinarity. The author would like to thank NGOs Agora CE and D21 (now Institute H21) for the help with the collection of the data and other helpful insights concerning the participatory budgeting in the Czech Republic. 